\title{
Distribution, Growth and Exploitation of Greater Silver Smelt (Argentina silus (Ascanius, 1775)) in Norwegian Waters 1980-83
}

\author{
Arne Johannessen \\ Department of Fisheries and Marine Biology, University of Bergen, Norway \\ and \\ Terje Monstad \\ Institute of Marine Research, Bergen, Norway
}

\begin{abstract}
Greater silver smelt (Argentina silus) occurs regularly in Norwegian waters, near bottom over large areas of the continental shelf. Due to a directed fishery for human consumption off midNorway, the stock was regularly monitored every spring and autumn. Data on distribution and abundance, as well as age, length and sexual maturity formed the basis for evaluation of the state of the stock and were applied for management advice to prevent overexploitation.

During the spring, greater silver smelt is more congregated at the continental slope and in the deeper parts on the shelf, while during the autumn it is mostly scattered over large areas. Immature specimens occur mainly at depths of less than $300 \mathrm{~m}$, and the mature individuals predominate at greater depths. Within specific areas, the age and length compositions vary between seasons, and hence growth variations from area to area were difficult to point out. However, there was a tendency for increased maximum length at increased latitude, and females were generally larger-atage than males.
\end{abstract}

The age at first sexual maturity occurs at a wide age range of $4-12$ years, with 7 years as the mean age for male and 6 years for female maturation. The sex ratio was about equal in shallow areas, but males frequently dominated at greater depths.

Key words: distribution, depth, greater silver smelt, growth, length, maturity, Norway, sex-ratio.

\section{Introduction}

Greater silver smelt (Argentina silus (Ascanius 1775)), also called Atlantic smelt or greater argentine, is common over large regions of the North Atlantic and is distributed at depths of 140-1 $400 \mathrm{~m}$ (Cohen, 1984). In Norwegian waters, specimens of greater silver smelt are commonly distributed close to the seabed in fjords and along the coast from Skagerrak to western Barents Sea, at depths of 200 to 600 m (Fig. 1).

Historically the greater silver smelt has been harvested as by-catch in the mixed industrial trawl fisheries, mainly in the North Sea, and the catches were exclusively processed for reduction. However, from the mid-1970s, a directed fishery for human consumption took place in the Skagerrak area as well as in the Sula depression off Møre (mid-Norway). The north- ern fishery developed rapidly, attracting more fishing vessels, and the fishing area expanded to other deep areas on the shelf and the slope. Since 1982, annual total allowable catches (TACs) were introduced for the area north of Stadt $\left(62^{\circ} \mathrm{N}\right)$. The total catches reached a maximum of 22000 tons in 1983 (Fig. 2). A TAC of 10000 tons was introduced north of $62^{\circ} \mathrm{N}$ in 1982. This increased up to 20000 tons when Russian by-catches from the blue whiting fishery were also included. The TAC was abandoned in 1992 and licensing of fishing vessels was maintained as the only restrictive management measure for the directed fishery of greater silver smelt north of $62^{\circ} \mathrm{N}$. There is also a Norwegian directed fishery for human consumption in the southern area (south of $62^{\circ} \mathrm{N}$ ), but this fishery is negligible in size. In addition, an international fishery takes place in the Skagerrak area as an unreported by-catch in the Pandalus shrimp fishery (Anon., 2000). 


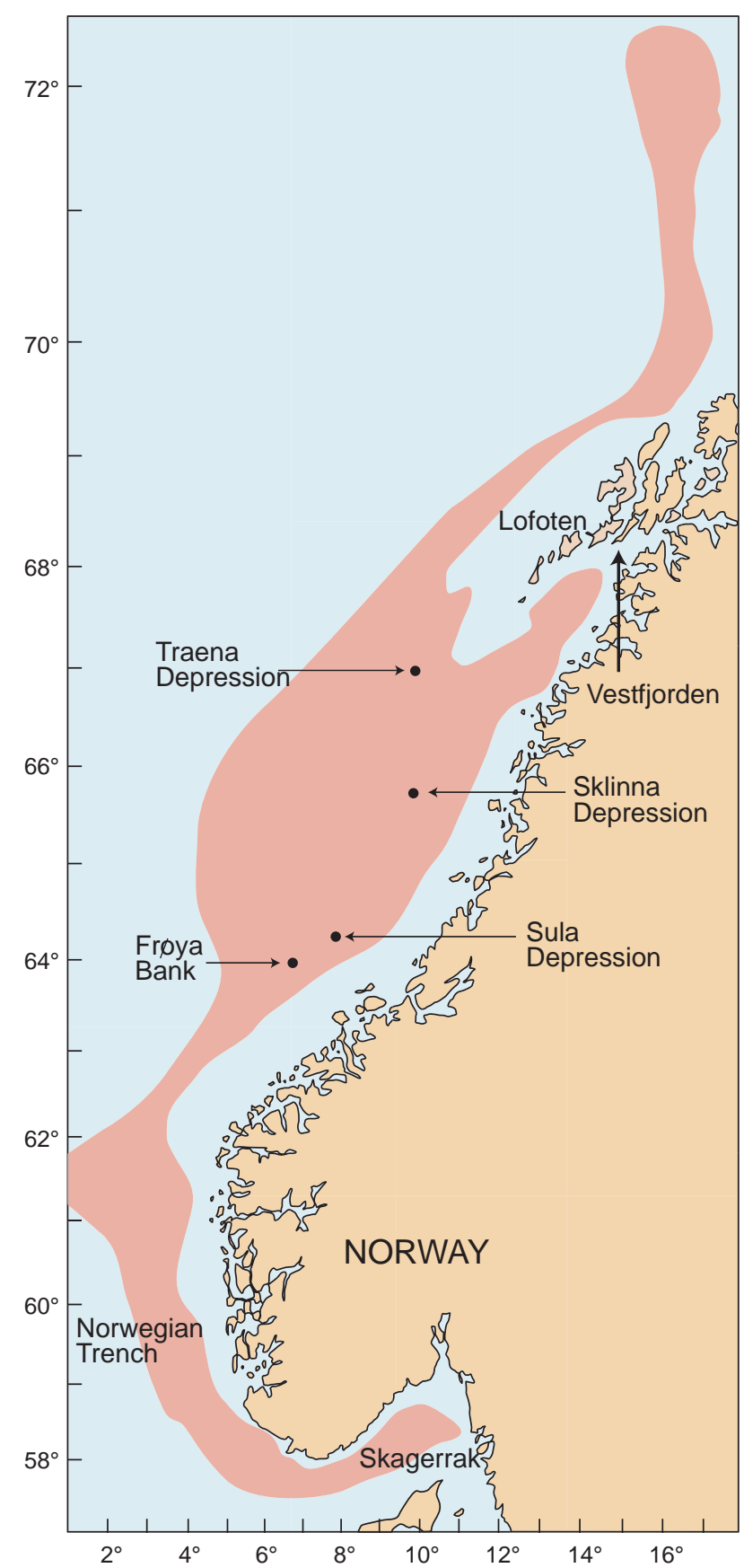

Fig. 1. Map showing distribution of greater silver smelt (Argentina silus) in Norwegian waters, based on research surveys in 1980-83.

Little effort was allotted to studies of greater silver smelt in Norwegian waters prior to 1980 . However, with greater prospects for continued increase in the fisheries for human consumption, demands for better management also increased. It was recognized better advice on the state of the stock and rational exploitation pattern would be possible if there was better biological knowledge and more regular monitoring of the stock. The Institute of Marine Research, Bergen, therefore initiated a three-year project (198083 ), with the overall aim to increase knowledge about the general biology and management of $A$. silus (Johannessen and Monstad, MS 1984), on which this paper is based. The data are considered relevant up to at least the early-1990s, after which no studies have been conducted on greater silver smelt in Norwegian waters. Data on this species from 1980-81 were published in Johansen and Monstad (MS 1982), whilst the remaining data have hitherto been given in internal reports only.

\section{Material and Methods}

Mapping and monitoring of the geographical distribution of greater silver smelt, as well as collection of biological samples (age, total length, sex, maturity), were conducted by the research vessels "Michael Sars" and "G.O. Sars" during the spring (April-May) and the autumn (Oct-Nov), 1980-83. Only data for the autumn 1981 (13 Oct-13 Nov) and the spring 1983 (6-27 April) are presented on fish distribution in the actual paper, because they best represent the season and area. In Fig. 3, survey tracks of the spring survey in 1983 are presented as an example. Along the tracks, fish were continuously recorded by means of an echo sounder with integrator connected. Recordings, expressed as mm deflection per nautical mile, with an average for every 5 nautical miles, were allotted to the various species or groups. For comparative purposes, the values recorded by the G.O. Sars were applied as the standard through intercalibration between vessels. Species in the echo recordings were captured using demersal or pelagic trawls and identified. It was difficult to distinguish fish recordings from the bottom layer and to identify particular species or groups of species from the mixture of fish recordings, but it was done by use of species composition in the trawl catches. Further application of acoustic data for biomass estimation of greater silver smelt was not considered reliable until 1989 when the new echo sounder EK500 was introduced (Monstad and Johannessen, 2003). A pre-determined bottom-trawling program was conducted in order to compare catch rates between seasons. A standard Granton shrimp trawl was used with an inner net in the cod-end of $11 \mathrm{~mm}$ mesh size and a vertical opening of $4-5 \mathrm{~m}$ at a towing speed of 3 knots. 


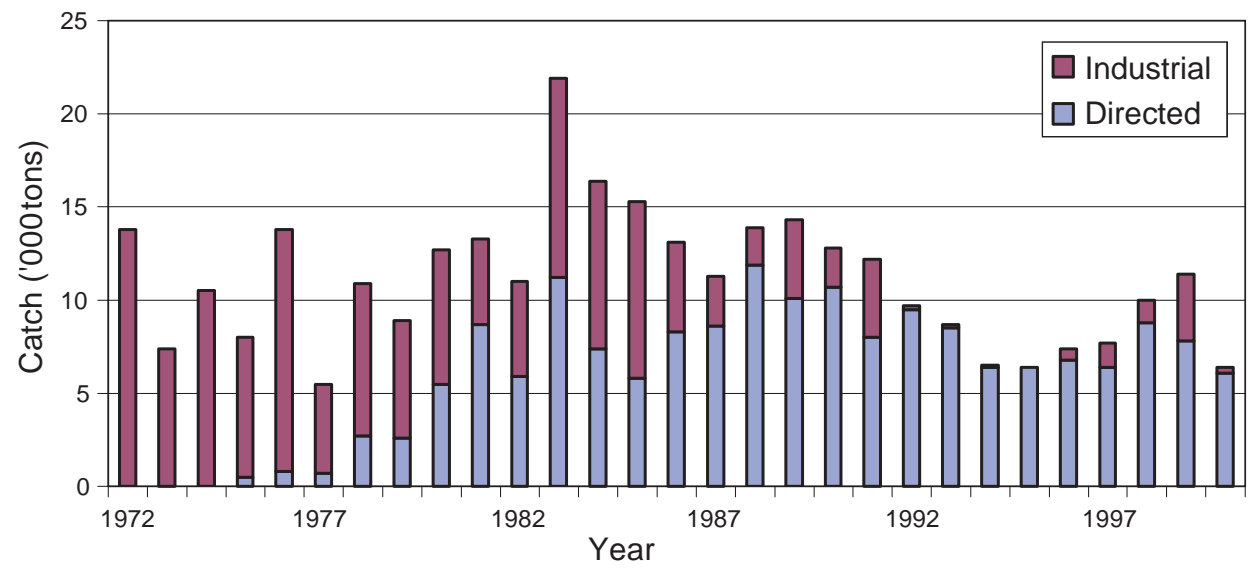

Fig. 2. Catches of greater silver smelt in Norwegian waters, 1972-2000, from directed fisheries (human consumption) and by-catches in the mixed industrial fisheries.

Supplementary sampling of fish data (total length, wet weight, sex, maturity and age), were conducted from landings of the commercial fisheries. The stage of maturity was based on macroscopic visual examination of gonads (maturity scale of 8 points used by Institute of Marine Research, Bergen (Anon., MS 1962). Age was determined by inspection of the otoliths, using a binocular microscope with incident light reflecting seasonal rings of whole otoliths cleared and mounted in plastic medium (Histokitt). Fishing logs of individual vessels were made available and provided valuable information about commercial catch rates at specific locations. Temperature data was collected with a CTD from the research vessels.

\section{Results and Discussion}

\section{Distribution}

Figures 4 and 5 illustrate relative densities of the horizontal distribution of "greater silver smelt" and "total fish" in autumn 1981 and spring 1983. Most echo recordings over the continental shelf off western Norway comprised a relatively homogeneous mixture of species with a benthopelagic or semipelagic life-style. Most often the greater silver smelt co-occurred with blue whiting (Micromesistius poutassou), ocean perch (Sebastes marinus) and Norway redfish (S. viviparus), but also Norway pout (Trisopterus esmarki) and silvery pout (Gadiculus argenteus thori) contributed in some areas, as well as blue ling (Molva dipterygia), saithe (Pollachius virens) and a number of other species (Table 1).
Greater silver smelt was distributed over most of the continental shelf deeper than $300 \mathrm{~m}$ from Stadt $\left(62^{\circ} \mathrm{N}\right)$ in the south to Vesterålen $\left(68^{\circ} \mathrm{N}\right)$ in the north. Further north along the shelf edge only faint recordings were found (Fig. 1). In general, the acoustic recordings were more dispersed and less dense in autumn than in spring (Fig. 4 and 5). Adult specimens were concentrated in some deeper areas on the shelf and the highest densities were found at about $400 \mathrm{~m}$ depth in the Sklinna $\left(65^{\circ} 30^{\prime} \mathrm{N}\right)$ and the Sula $\left(64^{\circ} \mathrm{N}\right)$ depressions and to the west of Lofoten and in the Vestfjord. The densest concentrations were observed in spring between $64^{\circ}$ and $67^{\circ} \mathrm{N}$ along the slope area adjacent to the Norwegian Sea, between 300-500 m depth. Up to $72^{\circ} 30^{\prime} \mathrm{N}$, greater silver smelt were recorded along the slope in the western part of the Barents Sea. The echo recordings of greater silver smelt along the slope were distributed more off-bottom compared with those in the shelf depressions.

Temporal variations in distribution apparently occur. During spring, field surveys usually took place in April-May, and only one year in March (1982). In March, only negligible levels were recorded in the more common spawning grounds on the shelf (Sula and Sklinna depressions). In April-May the aggregations of greater silver smelt increased, with higher congregations in these areas. During autumn, echo recordings generally provided low densities over the shelf itself and somewhat higher recordings in specific shelf depressions. Although variation in density was found between years, areas and seasons, the proportion of greater silver smelt made up a rather 


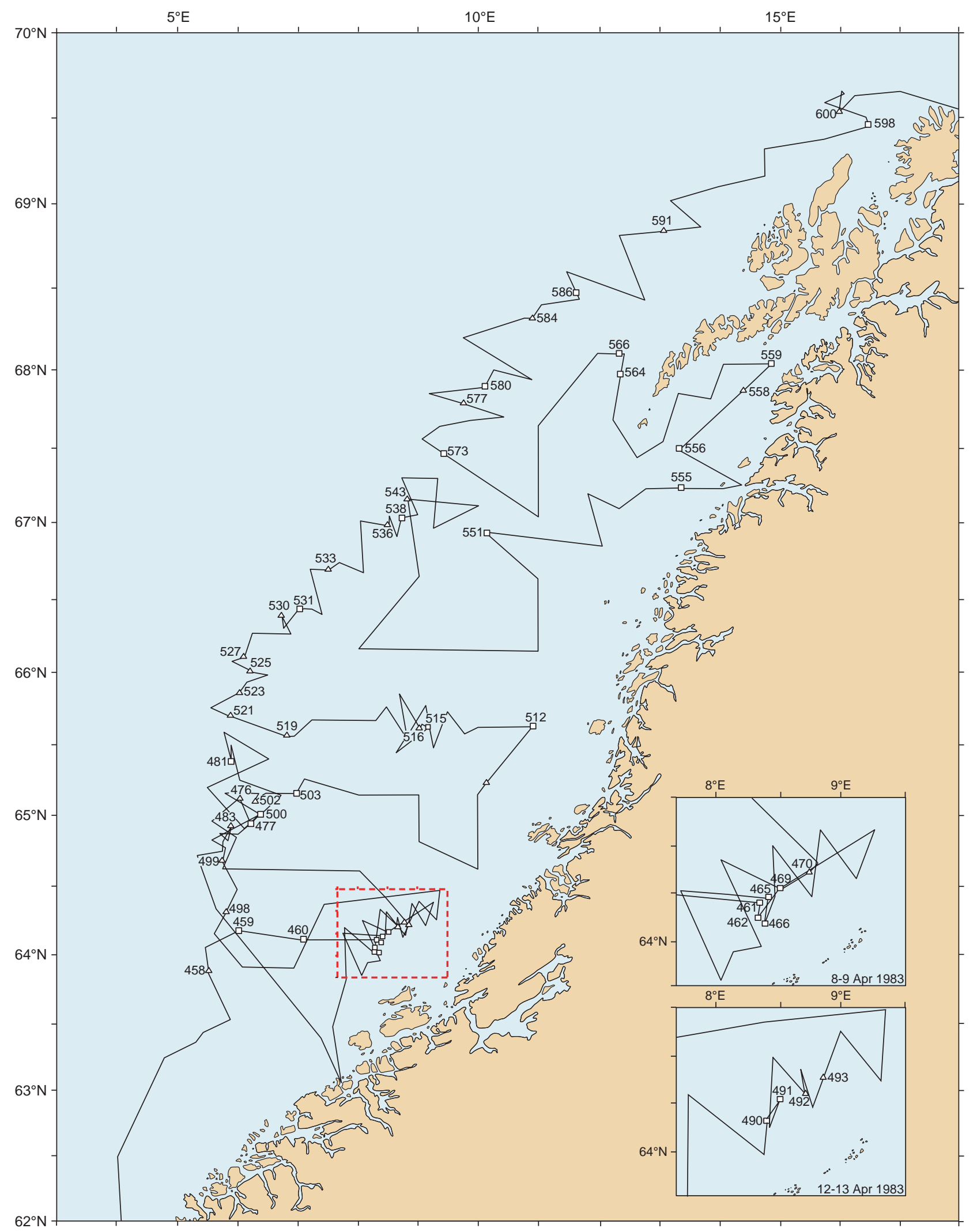

Fig. 3. Cruise tracks with trawl stations of RV G. O. Sars during 6-27 April 1983. Bottom (squares) and pelagic (triangles) stations. Cruise tracks with stations in the Sula depression inserted. 

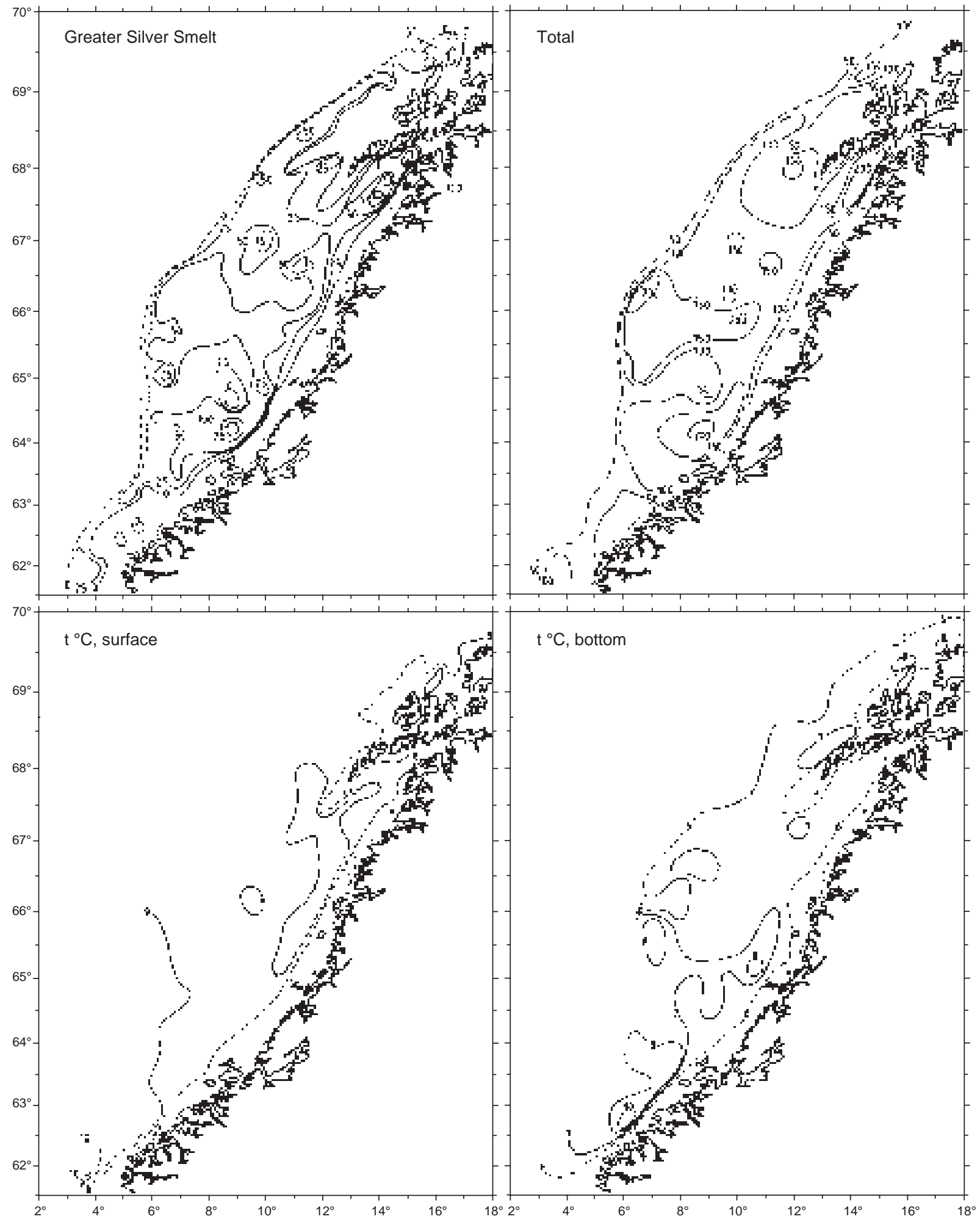

Fig. 4. Integrator output values (mm deflection per nautical mile) of greater silver smelt and "total fish", and distributions given as surface and bottom temperatures, autumn 1981. 




Fig. 5. Integrator output values (mm deflection per nautical mile) of greater silver smelt and "total fish", and distribution given as surface and bottom temperatures, spring 1983 (see also Fig. 3). 


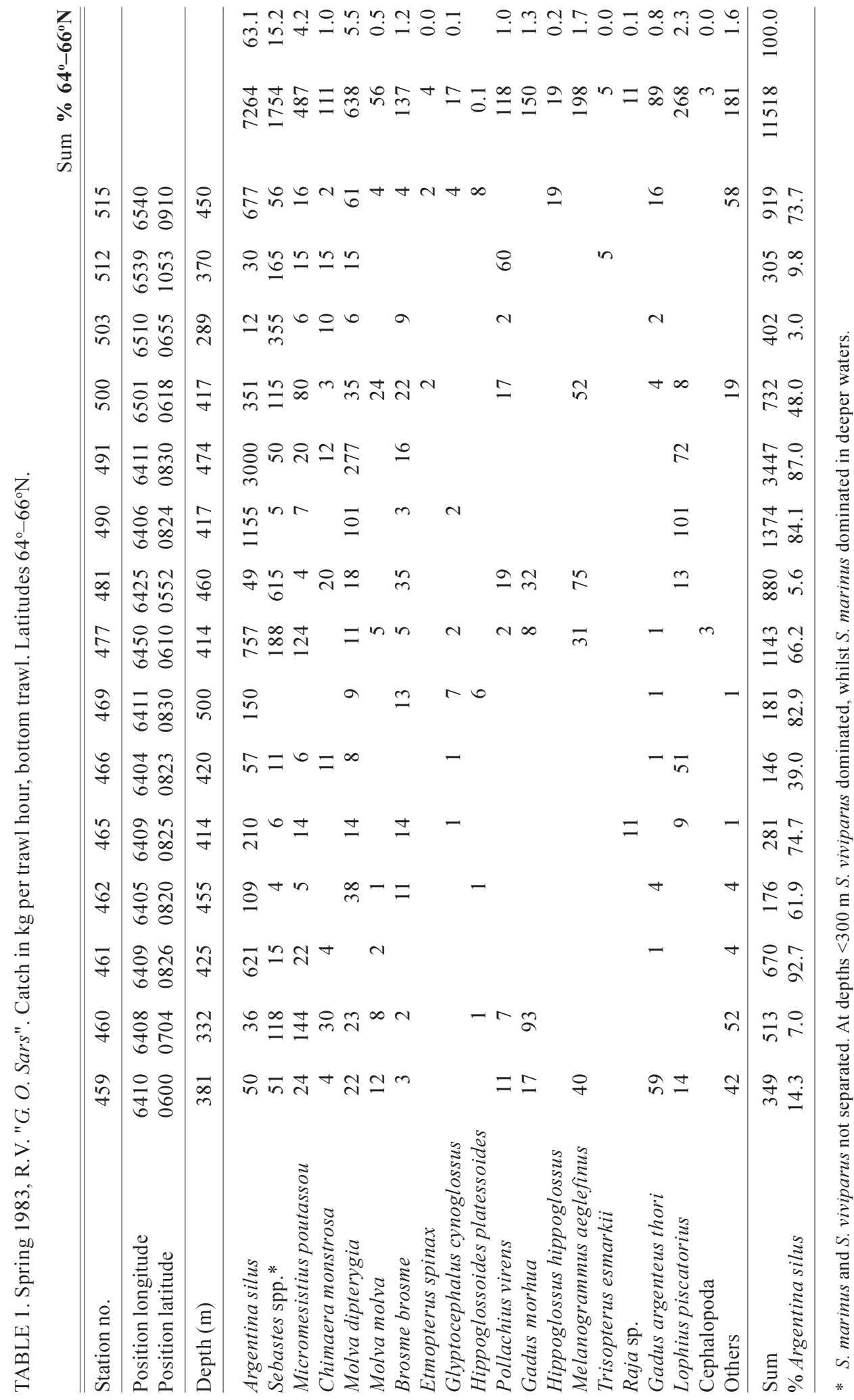


J. Northw. Atl. Fish. Sci., Vol. 31, 2003

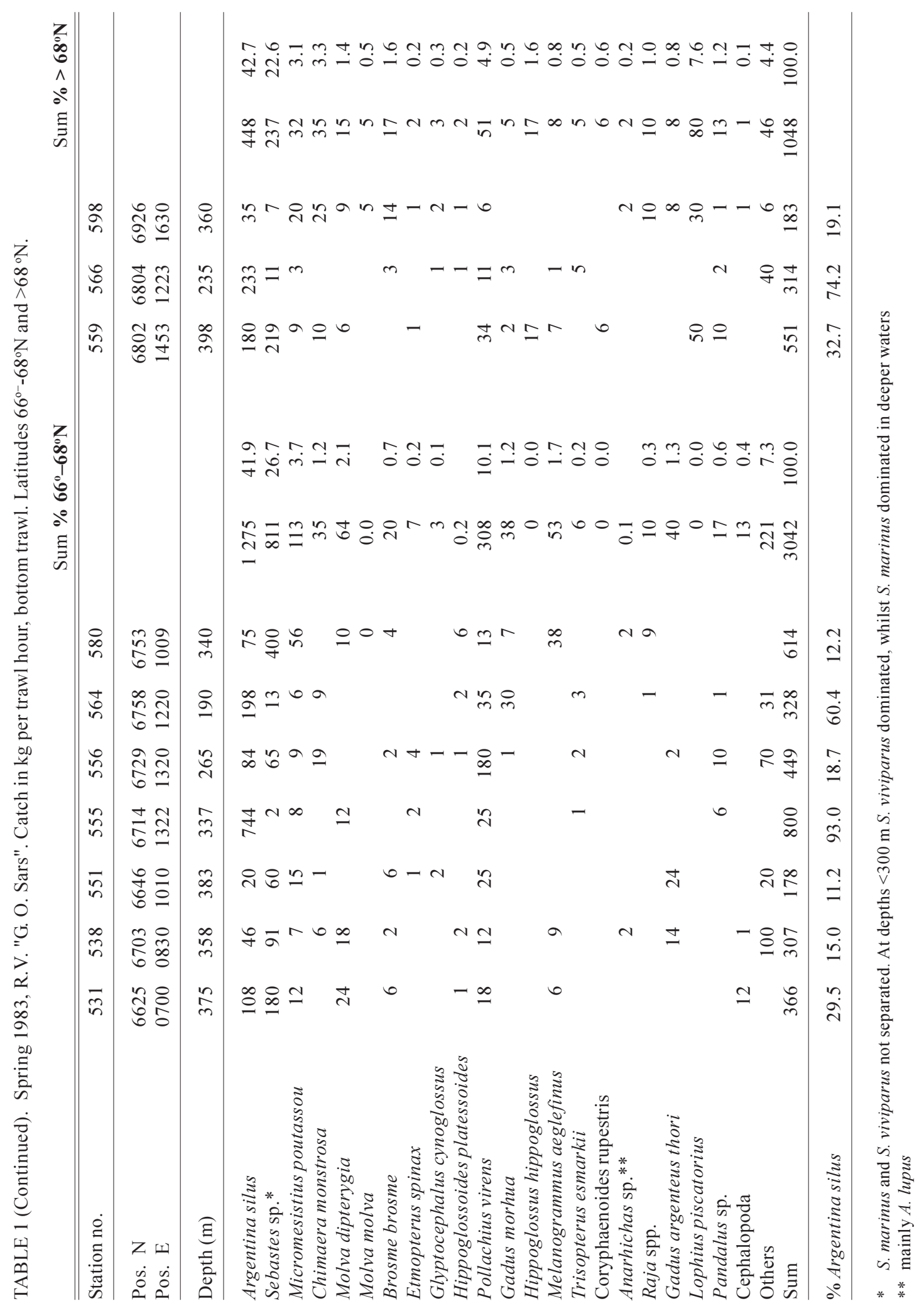


consistent part of total fish catches. As an example the species composition in trawl catches are shown for one season only, spring 1983 (Table 1).

\section{Temperature}

Although the average surface temperature may vary between years and seasons, the temperature close to the bottom is relatively stable (Fig. 4 and 5). Prevailing temperatures in the areas with greater silver smelt on the continental shelf, range between $5.4^{\circ} \mathrm{C}$ and $7.6^{\circ} \mathrm{C}$ (Fig. 4 and 5). In the slope area on the western continental shelf, sharp temperature gradients down to $1^{\circ} \mathrm{C}$ are not uncommon. Only minor fluctuations in temperature within the range mentioned above were observed between years.

\section{Commercial catches}

Figure 2 shows annual catches of $A$. silus taken by the directed fishery and reported by-catches of the industrial trawling fisheries in Norwegian waters. The fishery takes place mainly north of $62^{\circ} \mathrm{N}$ by bottom trawl in the shelf depressions at Sula and Sklinna, and along the continental slope by pelagic trawls just above the seabed. In this fishery it is mainly the mature adult portion of the stock that is exploited, whereas the immature stock in general made up a larger portion of the catches taken by the mixed industrial fishery in more shallow parts of the shelf. Since the directed fishery started in 1977, an increasing quantity of adults was landed with a maximum in 1983 of about 11000 tons, which exceeded the TAC of 10000 tons for the northern area. Monthly catches of greater silver smelt for human consumption in the area north of $62^{\circ} \mathrm{N}$ for the years $1980-83$ are given in Fig. 6. It shows that in January-February some fishing vessels commenced the catching activity, mainly in the Sula depression. Increasing participation of vessels generally took place in April-May, when also the largest catches of greater silver smelt were taken. During the years 1980-83 the number of vessels increased from 10 to about 30 in the limited number of fishing locations. In June the commercial fisheries came to an end, probably because the fish tended to disperse into shallower waters (Bergstad, 1993). In September of each year there was, however, a small rise in catches. Catch rates for the three most important fishing grounds in the early-1980s are given in Fig. 7. This figure shows that up to about 1981-82 a steady increase in catches were recorded during the first half of the year for the Sula and Sklinna depressions, with a reduction in 1983. For the grounds northwest of Frøya Bank, the catch rates were compara-

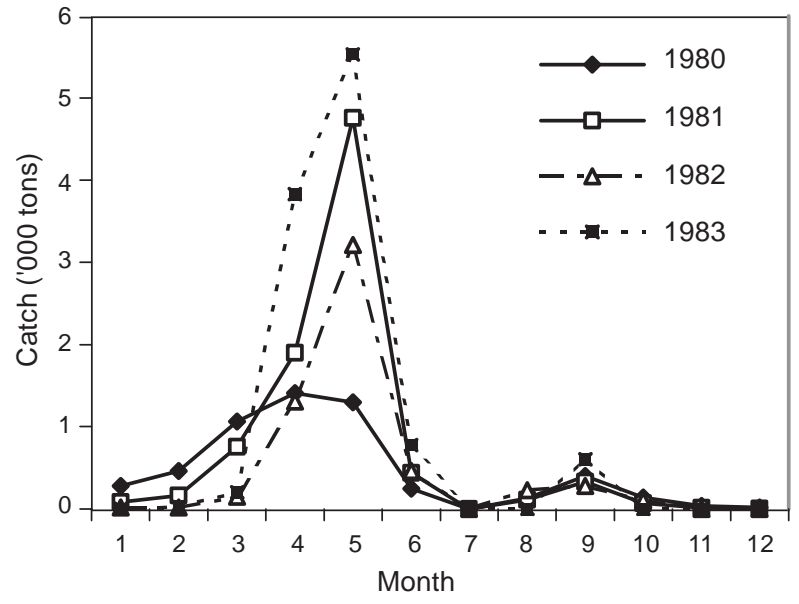

Fig. 6. Monthly catches of greater silver smelt (Argentina silus) for human consumption north of $62^{\circ} \mathrm{N}$.

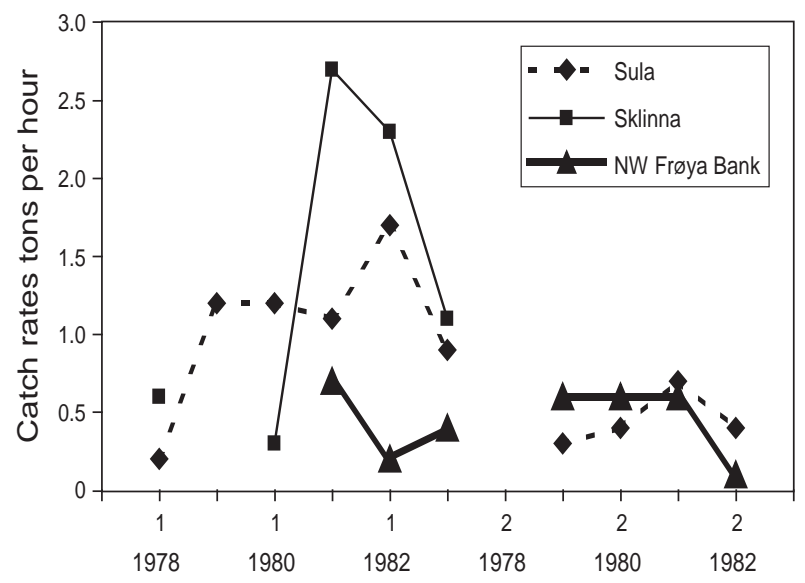

Fig. 7. Catch rates (tons per hour) of greater silver smelt (Argentina silus) in the first (1) and second (2) halfyear in the directed fishery from three localities (Sula depression, Sklinna depression and northwest of Frøya Bank), 1978-83.

tively low. The lower average catch rates for the Sula and Sklinna grounds in 1983 are probably related to the much higher number and activity of vessels. High fishing activity probably affects the greater silver smelt's behavior. Greater silver smelt is regarded as a good swimmer (Bergstad, 1993). Experiments with pelagic trawl shows that greater silver smelt also reacts vigorously to the trawling gear and hence is difficult to catch (unpublished data). This is also in accordance with fishermen reporting that greater silver smelt move away from locations of high fishing activity. The limited spatial range of many locations 
(depressions) on the shelf with aggregations of greater silver smelt, suggest that non-fishing locations within reasonable distance may be more attractive to move to when fishing activity is high and catch rates decline. For the second half of the year, mean catch rates were comparatively low and rather similar between the years. This indicates that the autumn is not the main fishing season and greater silver smelt is not distributed in such a dense pattern as with spawning aggregations in the spring.

\section{Pre-determined catching locations}

During 1980-83 some locations were trawled once every spring and autumn with standard bottom trawl in order to examine changes in stock structure by comparing relative length composition at similar times of the year. Also catch and effort data were collected to indicate possible differences between seasons. For two main fishing locations, the Sula and Sklinna depressions, relative high catch rates $(<3000$ $\mathrm{kg}$ per hr) were not uncommon, as shown for 1983 in Table 1. Due to large variations in catch rates, no apparent trend was traceable. The same kind of gear was applied and the same procedures were followed to conduct identical trawl hauls at temporal and spatial scales.

\section{Biological data}

Distribution of the sexes. A general feature of the greater silver smelt nursery grounds at depths of 200-300 $\mathrm{m}$ was that the sexes were equally distributed. In deeper areas $(>300 \mathrm{~m})$, the sexes were frequently found distributed in different proportions. Males dominated in the traditional fishing grounds at the Sklinna and the Sula depressions as well as at most other localities during the spring and the autumn. Most of the samples contained sexually mature adult specimens larger than $30 \mathrm{~cm}$ in size (Johannessen and Monstad, MS 1984). Features similar to these were not observed in the greater silver smelt in Vestfjorden. Neither did Bergstad (1993) find strong segregation of sexes with depth in the Norwegian Trench and the northeastern North Sea. However, he found some indications of slightly different distributions of the sexes in the eastern Skagerrak, where males tended to be more abundant deeper.

Higher proportions of females were occasionally obtained during pelagic trawling just above the bottom along the continental slope (unpubl. data). These observations suggest that females may be distributed more off-bottom than males. These are in accordance with those of Westhaus (1982), who concluded that females prefer more pelagic layers than males.
Maturity and spawning. Argentina silus reached maturity from a lower age of about 4 years, with the age at $50 \%$ maturity at about 6 years for females and 7 years for males (Fig. 8). Considering the slower growth rate of males (higher age-at-length in Fig. 9) vs females, both sexes seemed to mature at similar size (length). At 12 years of age, most greater silver smelt were mature. Mean age at first spawning of 57 years corresponded well with other reports from Skagerrak and western Norway (Keysler, 1968; Thorsen, MS 1979; Bergstad, 1993). Opposite to the findings in this paper as well as that of Beacham (1983) stating that females mature at an earlier age than males, Bergstad (1993) and several others (Thorsen, MS 1979; Westhaus, 1982; Magnusson, MS 1988) found that males seemed to mature at a younger age than females. This is not easy to explain, but methodological problems with sampling size may cause bias due to segregation of age and size groups with depth.

Spawning of greater silver smelt took place over large areas of the shelf and along the slope, in particular at depths greater than $300 \mathrm{~m}$. From March onwards the proportion of fish with running gonads increased in the catches, with spawning maximum in May (April-June). This is in accordance with observations by Bergstad (1993) that spawning in Skagerrak and northeastern North Sea primarily took place in April-May. Some spawning also took place in the autumn (Bergstad, 1993; Keysler, 1968; Wood and Raitt, 1968), until November off northern Norway (Johansen and Monstad, MS 1982).

Age and length. No significant differences in age or length were found between samples from the continental slope and locations on the shelf. Greater silver smelt is long-lived, with a significant portion of age groups being 20+ years. Age and length distributions from the area $64-66^{\circ} \mathrm{N}$ are shown in Fig. 10 for three depth intervals in two different years (1981 and 1983). This area represents the main fishing locations for greater silver smelt. Specimens in the size range $12-48 \mathrm{~cm}$ were caught, and age and length compositions were skewed towards higher values with increasing depth. Apart from cumulative frequencies of age $20+$ years, the age mode in 1981 tended to move from about 3 years at less than $300 \mathrm{~m}$ depth, towards 7 and 11 years at $300-400 \mathrm{~m}$ and deeper than $400 \mathrm{~m}$ depth, respectively. In 1983 the age modes at the same depth intervals were 5,9 and 9 years, respectively (Fig. 10). The mean lengths for the same depth intervals were in 1981: 27.7, 36.8 and $38.4 \mathrm{~cm}$, respectively, and in 1983: $28.6,35.0$ and $38.1 \mathrm{~cm}$. For each sex there was a clear trend with values of 

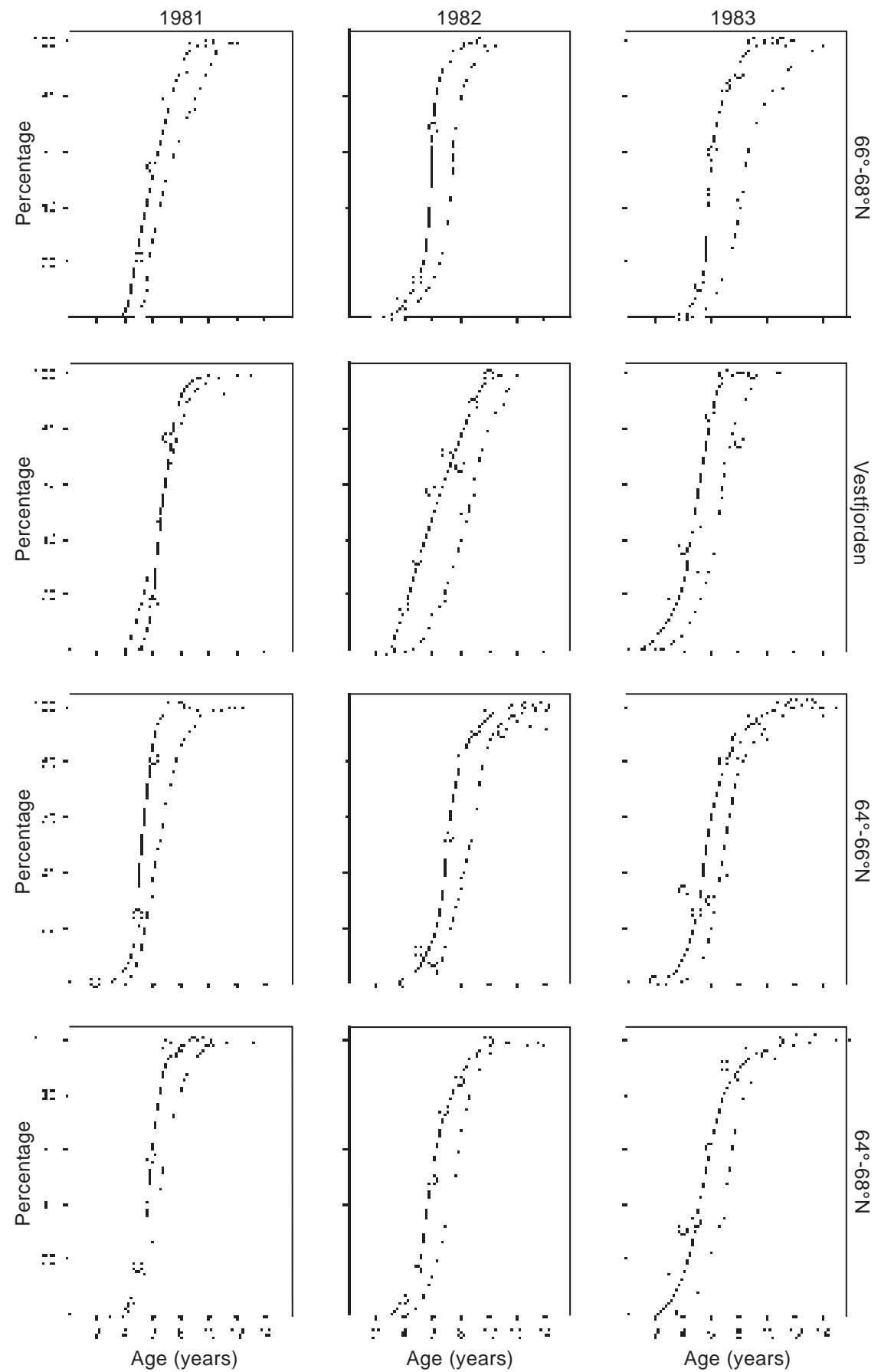

Fig. 8. Age and sex specific maturity ogives of greater silver smelt for three geographical areas and pooled, 1981-83.

age and length increasing with depth, and the most obvious changes occurred from less than $300 \mathrm{~m}$ towards greater depths. Thus, the nursery grounds of A. silus are obviously located at depths less than $300 \mathrm{~m}$.
Growth. Von Bertalanffy's growth curves were fitted to observed data on mean length-at-age of greater silver smelt in 1980-83 for the geographical areas limited by latitudes $62-64^{\circ} \mathrm{N}, 64-66^{\circ} \mathrm{N}$, $66-68^{\circ} \mathrm{N}$ and Vestfjorden (Fig. 9). Young specimens 


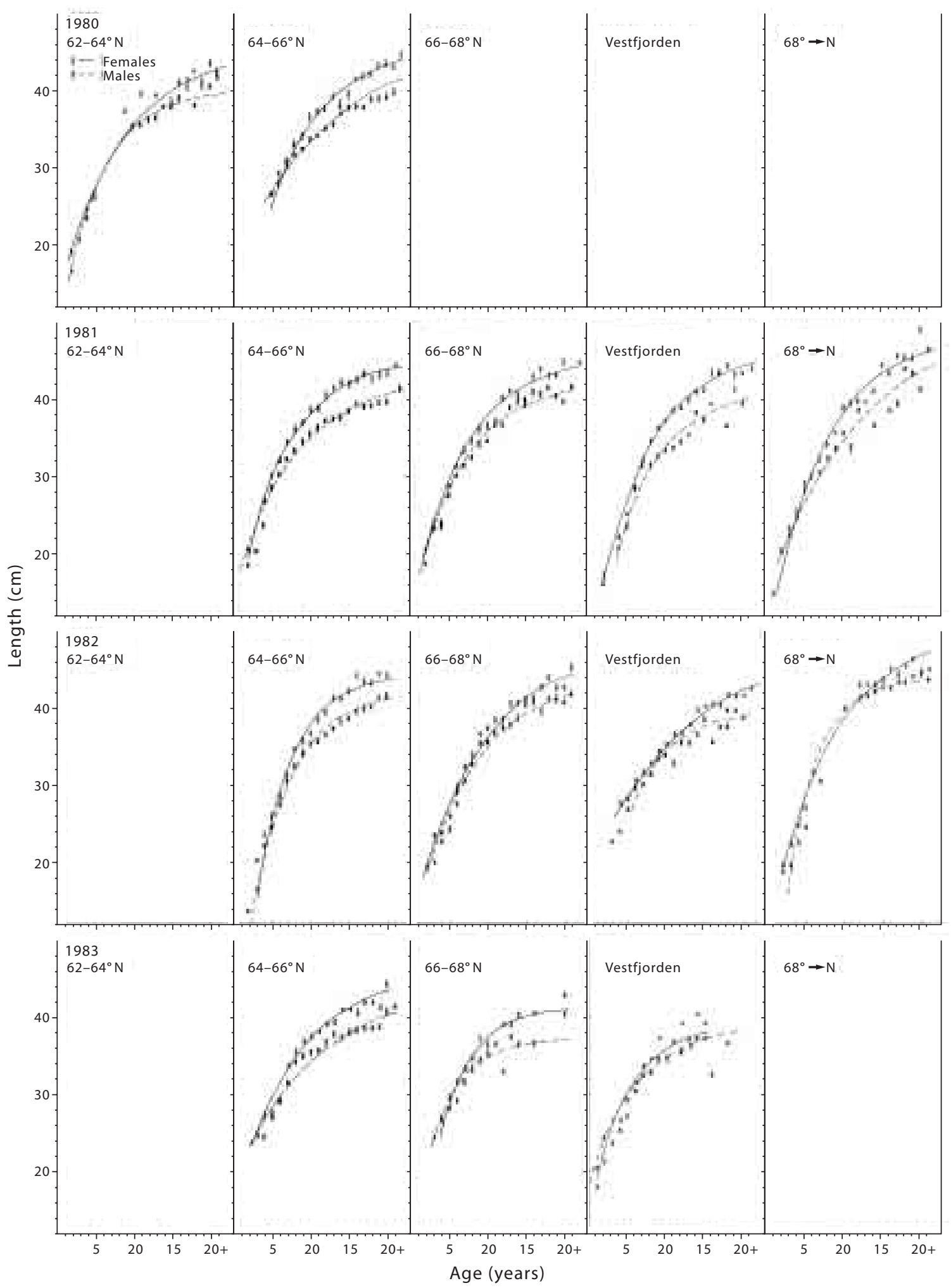

Fig. 9. Von Bertalanffy's growth curves fitted to estimates of mean length $( \pm \mathrm{SD})$ per age group of greater silver smelt for spring $1980-83$ in the geographical areas: $62-64^{\circ} \mathrm{N}, 64-66^{\circ} \mathrm{N}, 66-68^{\circ} \mathrm{N}$, Vestfjorden and north of $68^{\circ} \mathrm{N}$. 

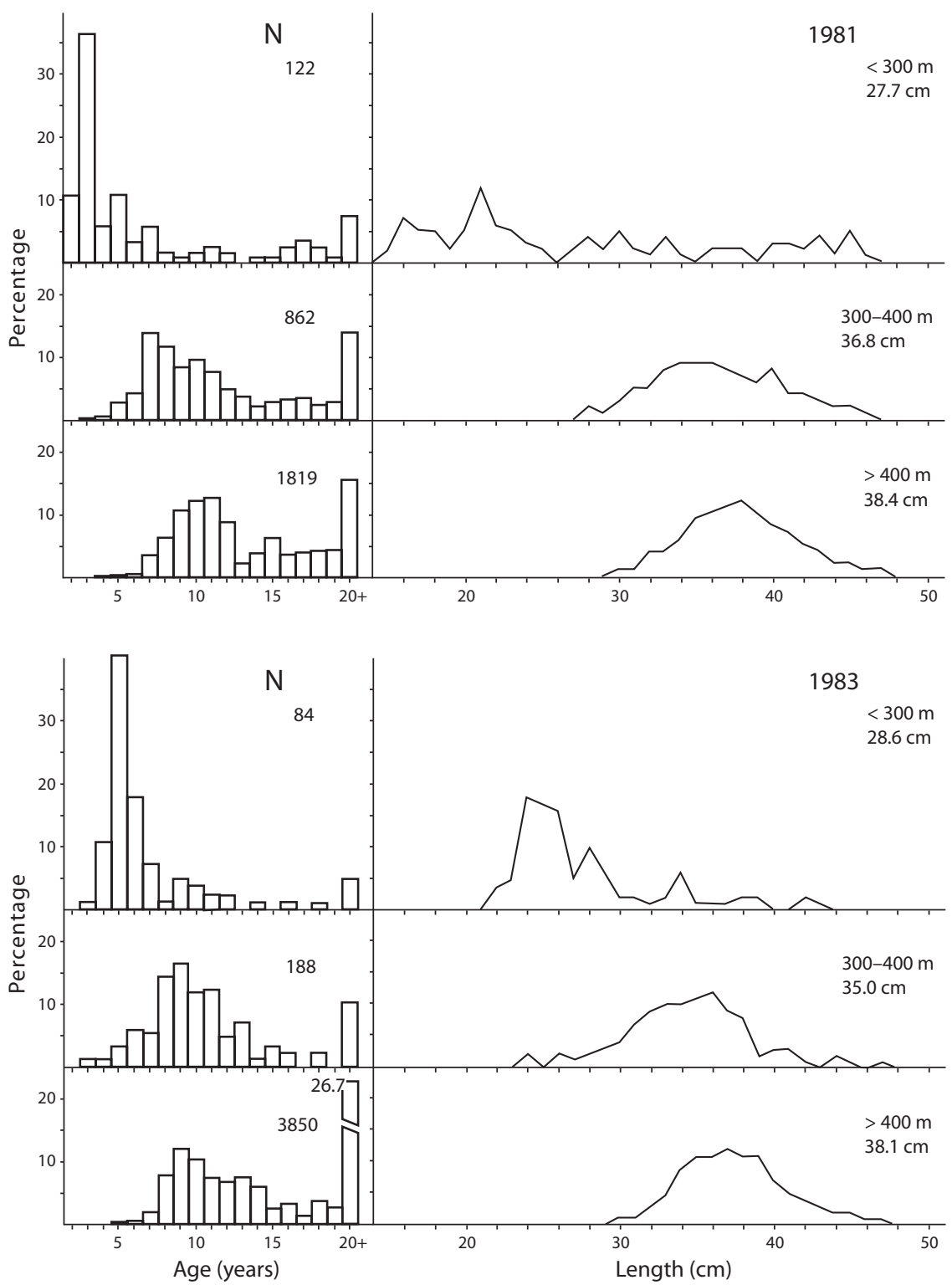

Fig. 10. Age and length distribution of greater silver smelt, spring 1981 and 1983. Bottom trawl samples from three depth intervals in the geographical area limited by the latitudes $64-66^{\circ} \mathrm{N}$.

$(<2$ years $)$ were underrepresented in all samples. After an age of about 6 years, divergence in growth appeared between males and females and a general feature was the lower length of males than females. The estimated growth coefficients of males and females were not different, but highly variable. From the observed data in 1981-82 it appeared that asymptotic length increased with increasing northern latitude. For the Vestfjorden area population growth pattern deviated from that of most other areas.

\section{Conclusion}

As an overall conclusion, the greater silver smelt tended to be scattered over large areas of the shelf and in spring congregated in the deeper parts and along the continental slope, which suggests some seasonal, vertical migration. An ontogenetic shift in vertical extension was observed, with preference for increasing depth with increasing age and size. Females were in general larger-at-age than males and were also 
found to mature at 6 years, one year prior to males ( 7 yrs). Several biological features (growth rate, age distribution, sex composition) of greater silver smelt in the Vestfjord area differed from most other locations, but variations due to sampling and size segregation with depth give no reason to exclude it as a different stock component. Developing new tagging techniques, which may provide information on environmentalbased behavior of greater silver smelt and other fragile fish living in deep water, provide challenges to achieve improved knowledge on stock composition and migration patterns.

\section{Acknowledgements}

The authors are grateful to Ø. Tangen for reading otoliths, J. Alvarez, B. V. Svendsen and S. Kolbeinson for assistance during preparation of figures and G. Ridgway for proofreading and an anonymous referee for improving the manuscript.

\section{References}

ANON. MS 1962. Recommendations adopted by the Herring Committee. ICES Rapp. Proc.-Verb., 1: 71-73.

MS 2000. Report of the Study Group on the Biology and Assessment of Deep-Sea Fisheries Resources (SGDEEP), ICES C.M. Doc., No. ACFM:8.

BEACHAM, T. D. 1983. Variability in size and age at sexual maturity of argentine, Argentina silus, on the Scotian Shelf in the Northwest Atlantic Ocean. Env. Biol. Fish., 8: $67-72$.

BERGSTAD, O. A. 1993 Distribution, population structure, growth, and reproduction of the greater silver smelt, Argentina silus (Pisces, Argentinidae), of the Skagerrak and the north-eastern North Sea. ICES J. Mar. Sci. 50: 129-143.

COHEN, D. M. 1984. Argentinidae (including Microstomatidae). In: Fishes of the north-eastern Atlantic and the Mediterranean, Vol. 1. P. J. P. Whitehead, M.-L. Bauchot, J.-C.Hureau, J. Nielsen and E. Tortonese (eds.). UNESCO, Paris, p. 386-391.

JOHANNESSEN, A., and T. MONSTAD. MS 1984. Bestandsundersøkelser på vassild (Argentina silus), 1980-1983. Final project report, project I.701.55. Norwegian Fisheries Research Council, Institute of Marine Research, Bergen, Norway, 22 p. + tables/figures (In Norwegian).

JOHANSEN, P. O., and T. MONSTAD. MS 1982. Preliminary results of Norwegian investigations on the greater silver smelt, Argentina silus (Ascanius). ICES C.M. Doc., No. G:10, 27 p.

KEYSLER, H. D. 1968. Investigations on the stocks of Argentina silus in waters off Norway, Iceland and Newfoundland. ICES Rapp. Proc.-Verb., 158: 58-64.

MAGNUSSON, J. V. MS 1988. On silver smelt, (Argentina silus Asc.) in Icelandic waters. ICES C.M. Doc., No. $\mathrm{G}: 39,12 \mathrm{p}$.

MONSTAD, T. and A. JOHANNESSEN. 2003. Acoustic recordings of greater silver smelt (Argentina silus) in Norwegian waters and west of the British Isles, 1989-1994. J. Northw. Atl. Fish. Sci., 31: 339-351 (this volume).

THORSEN, T. MS 1979. Populasjonsparametrar hos vassild, Argentina silus, utanfor Møre-Trøndelag og i Skagerrak. Master (cand. real.) Thesis, University of Bergen, Norway, $79 \mathrm{p}$.

WESTHAUS, S. P. 1982. Fischereibiologische Untersuchungen am Goldlachs (Argentina silus) im Seegebiet der Shetland-Färöer Inseln und in Gewässer westlich Grossbritanniens. Arch. FishWiss., 32 (1/3): 13-28.

WOOD, R. J. and D. F. S. RAITT. 1968. Some observations on the biology of the greater silver smelt, particularly in the North-eastern Atlantic Ocean. ICES Rapp. Proc.Verb., 158: 64-73. 